\title{
Toward marketing performance through supply chain management and knowledge sharing during the Covid19
}

\author{
Made Setini $^{a^{*}}$, Ni Nyoman Kerti Yasa ${ }^{\mathrm{b}}$, I Wayan Gede Supartha ${ }^{\mathrm{c}}$ and I Gusti Ayu Ketut Giantari ${ }^{\mathrm{d}}$
}

${ }^{a}$ Candidate Doctoral Program, Faculty of Economics and Business, Udayana University, Denpasar, Bali, Indonesia

${ }^{b}$ Profesor and Lecture Department of Management, Faculty of Economics and Business, Udayana University, Denpasar, Bali, Indonesia

${ }^{c}$ Profesor and Lecture Department of Management, Faculty of Economics and Business, Udayana University, Denpasar, Bali, Indonesia

${ }^{d}$ Lecture Department of Management, Faculty of Economics and Business, Udayana University, Denpasar, Bali, Indonesia

\section{H R O N I C L E}

\begin{tabular}{l}
\hline Article history: \\
Received January 27, 2021 \\
Received in revised format \\
January, 28, 2021 \\
Accepted May 202021 \\
Available online \\
May 20 2021 \\
\hline Keywords: \\
Social Capital \\
Knowledge Sharing \\
Supply Chain Management \\
Innovation \\
Marketing Performance
\end{tabular}

\section{A B S T R A C T}

\begin{abstract}
The culinary business sector is the choice of the COVID-19 pandemic; Women entrepreneurs and the informal sector are looking for a foothold in the COVID-19 pandemic, which will lead women to develop creative businesses. This study examines the role of supply chain management in mediating the role of social capital and marketing performance, innovation on marketing performance, and the mediating role of sharing knowledge on marketing performance among women entrepreneurs in Bali. Purposive sampling is used in the sampling technique, with 229 samples used, the Structural Equation Modeling (SEM-PLS) analysis technique with SmartPLS for application processing. The results showed that in order to increase sales, retain customers and reach a high market, good quality products and services owned by the supply chain, from social networking relationships and knowledge sharing, are needed. However, the increase in marketing performance cannot increase even though women entrepreneurs have strong relationships.
\end{abstract}

\section{Introduction}

Increased marketing performance can be seen by being able to retain consumers, increase the number of sales, and expand the market (Thomas et al., 2016). The success of informal small businesses, including in the scope of marketing, is influenced by social capital (Torres et al., 2019; Kebede, 2018). Social capital is a fundamental resource for women to become entrepreneurs and facilitate their marketing patterns (van Dijk et al., 2017). Social capital is not able to increase sales and produce women entrepreneurs (Subramony et al., 2018; Farida, 2017). Several studies have the view that marketing and business performance has increased by making innovations (Ganguly et al., 2019; Quah et al., 2021). In contrast to the opinion (Akhavan et al., 2015; Agyapong et al., 2017) the effect of social capital on women entrepreneurs, and the adoption of innovation does not always provide positive results in increasing female entrepreneurship. Resources are one of the strategies in improving marketing performance by adopting knowledge (Zhang et al., 2017). Apart from these an increase in marketing performance is required; all activities are planning, supply and demand, supply materials, produce products or present services (Gawankar et al., 2020). Manage and coordinate all these activities is a major problem in the supply chain, where the customer receives a product or service of good quality (Peridawaty et al., 2021). The performance of all activities in the supply chain requires a coordinating strategy and a strong relationship capital that is capable of creating innovation is required (Abidin, 2021).

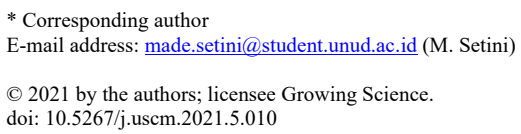




\section{Literature Review}

\subsection{Supply Chain Management on Marketing Performance}

Customers are the most important thing in marketing performance. Value chain alignment is an important customer need for this reason; integrated marketing orientation becomes a philosophy (Bruhn \& Schnebelen, 2017). This results in the predominance of goals such as customer satisfaction and loyalty and the long-term development of customer relationships. This orientation is expressed in the increasing importance of customer relationship management (CRM) (Sutono, 2019). Indicators describe marketing performance, namely there is demand stimulation (sales), which is a direct effect on income. Marketing activity seeks to encourage customers to accept price increases; this will potentially increase sales volume. Customer performance is related to the effects on customer satisfaction and customer loyalty (Sudari et al., 2019). In this context, marketing measures can form long-term customer relationships that have a long-term effect on customer value for a company (Ali \& Anwar, 2021).

\subsection{Knowledge Sharing on Marketing Performance}

Sharing knowledge which is a characteristic of the KBV theory which in the end will build human resources that interterminate so that in the end it achieves a good evaluation which is a solved problem in one organization (Salehzadeh et al., 2017). Sharing knowledge sourced from KBV makes the process of increasing the performance business in organizational activities (Lei et al., 2021). Knowledge sharing refreshes to activities where knowledge is shared or exchanged in various forms from individuals, groups, or organizations to others (Markovic \& Bagherzadeh, 2018). Knowledge is information that has been analyzed and organized so that it can be understood and used to solve problems and make decisions (Markovic $\&$ Bagherzadeh, 2018).). Based on the origin of knowledge and its development, according to (Boadu et al., 2018; Rumanti et al., 2018) knowledge management is divided into two, namely: Tacit: basically knowledge tacit is personal, developed through experiences that are difficult to formulate and communicate. Knowledge sharing creates opportunities to take advantage of existing resources and influences acting as a transmission channel for information, and provides access to resources so as to be able to seek opportunities and increase in the market (Tata \& Prasad, 2015).

\subsection{Innovation and Marketing Performance}

Innovation has found a more important role in the evolution of social and economic structures than the modern economy is considered in some studies to be an innovation-based economy (Zhou et al., 2019). Innovation is defined as the extent to which an organization offers new or better products and services to the market (Ganguly et al., 2019). Innovation means a product idea, information technology, institutions, behavior, values, and new practices, or in other words, innovation is the modification or discovery of ideas for continuous improvement and development to meet customer needs. SanchezFamosoa et al. (2019). To achieve continuous innovation, managers need to focus not only on products, technology, and processes but also on organizational culture, norms, and values that govern the organization (Srisathan et al., 2020). Performance is a description of the level of achievement of implementation. a program of activities or policies in realizing the goals, objectives, vision, and mission of the organization as outlined in the strategic planning of an organization. Women entrepreneur is a company's effort to identify and meet consumer needs and tastes (Leal-Rodríguez \& AlbortMorant, 2016). whereas according to (Agyapong et al., 2017; Putra et al., 2020) Women entrepreneur is a company's efforts to identify and fulfill needs and consumer taste, can be viewed as a concept used in measuring the extent to which market performance can be achieved by a product that has been produced. One of the anchors of company performance is women entrepreneurs, which means that good women entrepreneurs will create good company performance too (Sugiyarti et al., 2018). Women entrepreneur is a concept for measuring the market performance of a product. Zhou et al. (2019), every company has an interest in knowing how the market performance of the products offered is, what is the reflection of the success of their business in the business world Muehlfeld et al. (2012).

\subsection{Social Capital on Marketing Performance}

Social capital is very important in the process of knowledge transformation and exploitation, namely the ability to combine existing and newly assimilated knowledge and apply it to company operations and strategies (Allameh, 2018; van Dijk et al., 2016; Lee, 2015; Kim \& Shim., 2018). Good interpersonal relationships help individuals feel psychologically secure, this process stimulates creativity, social capital also allows people to seek advice to solve problems and generate new insights (Sanchez-Famosoa et al., 2019; Farida, 2017; Dastourian et al., 2017) . Trust in social capital provides safer access to a heterogeneous set of resources that can drive innovation (Rass et al., 2013; Moqbel \& Nah, 2017). The transfer of information and technology from one corporate department to another can drive the evolution of discoveries as it smooths out the specialization of knowledge resource integration (Dhir et al., 2021). Research by Lee et al. (2016) show that the quality of knowledge sharing positively affects the manufacturing performance of companies in China.

Based on empirical studies and theories, the research hypotheses are:

\section{H1: Social Capital has a positive effect on Marketing Performance.}


$\mathbf{H}_{2}$ : Social Capital has a positive effect on Knowledge Sharing.

$\mathbf{H}_{3}$ : Social Capital has a positive effect on Supply Chain Management.

$\mathbf{H}_{4}$ : Social Capital has a positive effect on Innovation.

H5: Innovation has a positive effect on Supply Chain Management.

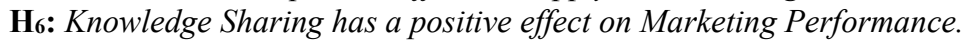

H7: Supply Chain Management has a positive effect on Marketing Performance.

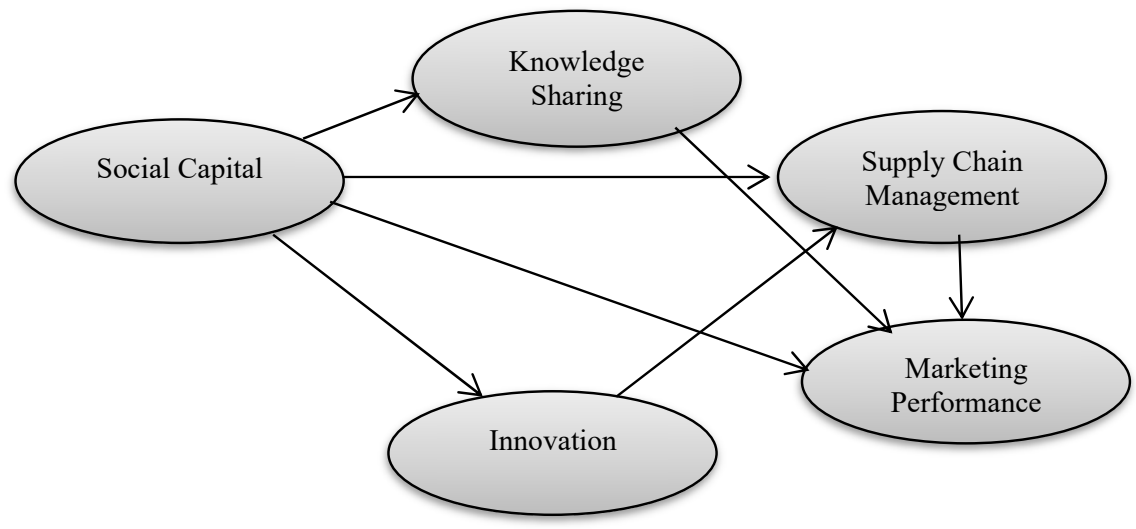

Fig 1. Model Concept

\section{Method}

The research method uses the principle of positivism in informal women entrepreneurs in Bali. The sampling technique used purposive sampling. The sample was taken from the population of women in the informal sector in Bali, and the data was collected using a structured questionnaire that was distributed online. The provisions are the respondent as the owner or manager of the business. The provision for the number of samples uses a formula Hair et al. (2014), which is 5 to 10 multiplied by the indicator so that the sample of 229 is sufficient to represent women entrepreneurs in Bali. Structured data collection techniques in this study used an online questionnaire with a Likert answer scale to measure the variables used to contain closed statements. Social capital cities measurements made by (Burt, 1997; Muniady et al., 2015). Knowledge Sharing quotes from research (Kim \& Shim; 2018). Supply Chain Management indicators cite research (Bruhn \& Schnebelen, 2017); Innovation indicators are used by research (Rumanti et al., 2018; Allameh, 2018) and the marketing performance variables of the researchers (Sugiyarti et al., 2018).

\section{Results}

\subsection{Characteristics of respondents}

Respondent profiles were collected from 9 research areas consisting of 1 city and 8 districts with 229 respondents in the province of Bali. It shows that the business actors where the business has been run for more than 4 years is $36.2 \%$ and less than 2 years $34.5 \%$, the remaining is between 3-4 years, the average business actor is the owner himself, $93.1 \%$ the remaining $6.9 \%$ is running someone else's business. The number of workers is mostly less than 3 people, namely $72.4 \%$, between $4-6$ as much as $22.4 \%$ and the remaining 5, $2 \%$ are those who have more than 3 workers, and $50 \%$, on average have a bachelor's level of education as much as $44.8 \%$.

\subsection{Evaluation of the Outer Model Evaluation (measurement model)}

Testing the reliability test construct using composite reliability (CR), average variable extracted (AVE), and alpha a (AVE) is 0.50 or more (Hair et al., 2014) shown in Table 1.

Table 1

Test of the validity and reliability

\begin{tabular}{cccc}
\hline Variabel & Cronbach's Alpha & Composite Reliability & Average Variance Extracted (AVE) \\
\hline Social Capital & 0.9 & 0.9 & 0.7 \\
Knowledge Sharing & 0.8 & 0.8 & 0.6 \\
Supply Chain Management & 0.7 & 0.7 & 0.6 \\
Innovation & 0.8 & 0.8 & 0.6 \\
Marketing Performance & 0.8 & 0.8 & 0.6 \\
\hline
\end{tabular}


$R$ Square $\left(R^{2}\right.$ test $)$

Parameter coefficient of determination or R-square $\left(\mathrm{R}_{2}\right.$ Shows the combination of the effects of exogenous variables on endogenous variables (Hair et al., 2014) as for the value R2 that is accepted is included in the weak model if the value of 0.25 is included in the moderate model if the value is 0.5 while it is in the strong $\mathrm{R}^{2}$ category if it has a model value of 0.75 (Hair et al., 2014), and the model is said to be weak if the model value is 0.19 . In this study, the value for $\mathrm{R}^{2}$ Innovation has a value of 0.200 in the weak model, while the other variables have an $\mathrm{R}^{2}$ value between $0.395-0.454$ meaning that all variables fall into the medium category in Table 2.

Table 2

R-square test results

\begin{tabular}{lcc}
\hline Variable & R Square & R Square Adjusted \\
\hline Innovation & 0.200 & 0.192 \\
Knowledge Sharing & 0.395 & 0.389 \\
Marketing Performance & 0.455 & 0.438 \\
Supply Chain Management & 0.454 & 0.442 \\
\hline
\end{tabular}

Source: Results of Data Processing 2021

\section{$Q$-square (Predictive Relevance)}

Criteria for the strength and weakness of the model measured by the value of $Q 2$ are 0.35 (strong model), 0.15 (moderate model), and 0.02 (weak model) (Choshin \& Ghaffari, 2017).

Value of Q2 can be calculated as $Q^{2}=1-\left(1-R_{1}^{2}\right)\left(1-R_{2}^{2}\right)=0.865$. The Q-square calculation yields a value of 0.865 or $86.5 \%$, which means that the model has a very good observation value. This means that $86.5 \%$, the relationship between variables can be explained by the model. Based on the 2 results of the Inner Model assessment above where R2 is at a moderate and strong level and Q2 is at a very good level.

The goodness of fit (GoF)

The goodness of fit (GoF) test is to measure the accuracy of the overall model.

Average R2 $=0.200+0.395+0.455+0.454 / 4=0.62$

Average AVE $=((0.7)+(0.6)+(0.6)+(0.6)+(0.6)) / 5=0.62$

Root of average AVE $\sqrt{ } 0.694=0.785$

Root of average AVE $\times$ average $\mathrm{R}^{2}=0.785 \times 0.62$

$\mathrm{GoF}=0.48$. (Large)

So, the overall evaluation research model can be expressed well and we can further proceed with the analysis of hypothesis testing

\section{Estimate for Path Coefficients}

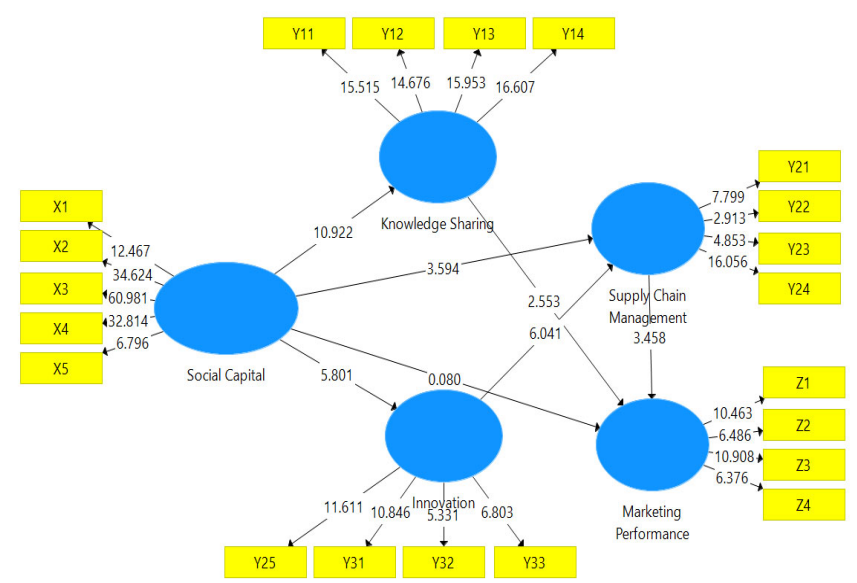

Fig 2. Bootstrapping Result 
Table 3

Test Results Path Coefficient

\begin{tabular}{|c|c|c|c|c|c|}
\hline & Variable & Original Sample(0) & T-values & p-values & Description \\
\hline H1 & Social Capital $\rightarrow$ Marketing Performance & -0.009 & 0.085 & 0.933 & Not Significant \\
\hline $\mathrm{H} 2$ & Social Capital $\rightarrow$ Knowledge Sharing & 0.628 & 10.046 & 0.000 & Significant \\
\hline H3 & Social Capital $\rightarrow$ Supply Chain Management & 0.300 & 3.365 & 0.000 & Significant \\
\hline H4 & Social Capital $\rightarrow$ Innovation & 0.448 & 5.725 & 0.000 & Significant \\
\hline H5 & Innovation $\rightarrow$ Supply Chain Management & 0.483 & 5.978 & 0.000 & Significant \\
\hline H6 & Knowledge Sharing $\rightarrow$ Marketing Performance & 0.333 & 2.675 & 0.008 & Significant \\
\hline H7 & Supply Chain Management $\rightarrow$ Marketing Performance & 0.414 & 3.569 & 0.000 & Significant \\
\hline
\end{tabular}

Source: Results of Data Processing 2021

Based on the results of the direct relationship analysis from Table 3, it indicates that the hypothesis (H1 is rejected, H2, H3, H4, H5, H6 and $\mathrm{H} 7$ are accepted).

\section{Discussion}

\subsection{The Effect of Social Capital on Marketing Performance}

Social capital is very important in the process of knowledge transformation and exploitation, namely the ability to combine existing and newly assimilated knowledge and apply it to company operations and strategies (Allameh, 2018; van Dijk et al., 2016; Lee, 2015; Kim \& Shim., 2018). Good interpersonal relationships help individuals feel psychologically secure, this process stimulates creativity, social capital also allows people to seek advice to solve problems and generate new insights (Sanchez-Famosoa et al., 2019; Farida, 2017; Dastourian et al., 2017). Trust in social capital provides safer access to a heterogeneous set of resources that can drive innovation (Rass et al., 2013; Moqbel \& Nah, 2017). The transfer of information and technology from one corporate department to another can drive the evolution of discoveries as it smooths out the specialization of knowledge resource integration (Dhir et al., 2021). Research by Lee et al. (2016) show that the quality of knowledge sharing positively affects the manufacturing performance of companies in China. Knowledge sharing provides information and provides access to external resources. An evolving and unpredictable social environment, innovation is considered by many to be the driving force for strategic competitiveness and sustainable value in Ghana, innovation across MSMEs is necessary not only for organizational survival but also for enhancing business performance (Gemünden et al., 2018), brings various aspects of innovation to light to understand its relationship with firm performance.

\subsection{The Influence of Social Capital on Knowledge Sharing, Supply Chain Management, Innovation}

The results of testing the effect of social capital on knowledge sharing, Supply Chain Management and Innovation show that social capital has a positive and significant effect. Social capital plays a role in the exchange of information and knowledge that is useful in business, especially in the informal sector. Research Tata and Prasad's (2015); Allameh (2018) with different research backgrounds found the same research results that structural, relational, and cognitive social capital gave positive results on knowledge sharing because it would increase intelligence. Having a strong network indirectly creates new customers and is important in marketing performance. The supply value chain created from the network becomes a philosophy of marketing success. Supply chain hardening is a long-term relationship that creates customer satisfaction so as to be able to retain old customers, which is the goal of marketing performance. So this research is in line with research (Bruhn \& Schnebelen, 2017; Sutono, 2019; and Sudari et al., 2019). Knowledge sharing provides information and provides access to external resources. An evolving and unpredictable social environment, innovation is considered by many to be the driving force for strategic competitiveness and sustainable value in Ghana, innovation across MSMEs is necessary not only for organizational survival but also for enhancing business performance (Gemünden et al., 2018).

\section{Conclusions and Suggestions}

Supply Chain Management is able to maintain a supply chain that originates from the relationships of women entrepreneurs in Bali which creates the ability to innovate in realizing increased marketing performance. The quality of resources, namely sharing of knowledge, is the basis for building sustainable business management

\section{Acknowledgments}

We aknowledge that the completion of this research is due to the assistance of teachers in the provinces of Bali, Indonesia, and special thanks goes to them. Thanks also to the anonymous referees for constructive comments on the previous version of this paper. 


\section{References}

Abidin, Z. (2021). The effects of information technology and operation performance on service supply chain management practices with moderating effect of capital owners. Uncertain Supply Chain Management, 9(2), 413-420.

Ali, BJ, \& Anwar, G. (2021). The Effect of Marketing Culture Aspects of Healthcare Care on Marketing Creativity. International Journal of English Literature and Social Sciences, 6(2), 171-182.

Allameh, S.M. (2018). Antecedents and consequences of intellectual capital: The role of social capital, knowledge sharing and innovation. Journal of Intellectual Capital,19(5), 1469-1930. https://doi.org/10.1108/JIC-05-2017-0068

Akhavan, P., Hosseini, S.M., Abbasi, M. and Manteghi, M. (2015). Knowledge-sharing determinants, behaviors, and innovative work behaviors: An integrated theoretical view and empirical examination. Journal of Information Management, 67(5), 562-591. https://doi.org/10.1108/AJIM-02-2015-0018

Agyapong, F. O., Agyapong, A., \& Poku, K. (2017). Nexus between social capital and performance of micro and small firms in an emerging economy: The mediating role of innovation. Cogent Business \& Management, 4(1), 1309784. https://doi.org/10.1080/23311975.2017.1309784

Bruhn, M., \& Schnebelen, S. (2017). Integrated marketing communication - from an instrumental to a customer-centric perspective. European Journal of Marketing, 51(3), pp. 464-489. https://doi.org/10.1108/EJM-08-2015-0591

Burt, R. S. (1997). A note on social capital and network content. Social Networks, 19(4), $355-373$. https://doi.org/10.1016/S0378-8733(97)00003-8

Boadu, F., Xie, Y., Du, Y. F., \& Dwomo-Fokuo, E. (2018). MNEs subsidiary training and development and firm innovative performance: The moderating effects of tacit and explicit knowledge received from headquarters. Sustainability, 10(11), 4208. https://doi.org/10.3390/su10114208

Choshin, M., \& Ghaffari, A. (2017). An investigation of the impact of effective factors on the success of e-commerce in small-and medium-sized companies. Computers in Human Behavior, 66, 67-74. https://doi.org/10.1016/j.chb.2016.09.026

Dastourian, B., Kawamorita, K. H., Seyyed Amiri, N., \& Moradi, S. (2017). Women entrepreneurship: effect of social capital, innovation and market knowledge. AD-minister, 30, 115-130. https://doi.org/10.17230/ad-minister.30.6

Dhir, S., Rajan, R., Ongsakul, V., Owusu, R. A., \& Ahmed, Z. U. (2021). Critical success factors determining performance of cross-border acquisition: Evidence from the African telecom market. Thunderbird International Business Review, 63(1), 43-61. DOI: 10.1002/tie.22156

Farida N. (2017). Antecedent of innovation and marketing performance in the Batik industry. Advanced Science Letters 23(1), 471-4. Doi:10.1166/asl.2017.7226

Gawankar, S. A., Gunasekaran, A., \& Kamble, S. (2020). A study on investments in the big data-driven supply chain, performance measures and organisational performance in Indian retail 4.0 context. International Journal of Production Research, 58(5), 1574-1593.

Ganguly, A., Talukdar, A., \& Chatterjee, D. (2019). Evaluating the role of social capital, tacit knowledge sharing, knowledge quality and reciprocity in determining innovation capability of an organization. Journal of Knowledge Management, 23(6), 1105-1135. https://doi.org/10.1108/JKM-03-2018-0190

Gemünden, H. G., Lehner, P., \& Kock, A. (2018). The project-oriented organization and its contribution to innovation. International Journal of Project Management, 36(1), 147-160. https://doi.org/10.1016/j.ijproman.2017.07.009

F. Hair Jr, J., Sarstedt, M., Hopkins, L., \& Kuppelwieser, V. (2014). Partial least squares structural equation modeling (PLS-SEM): An emerging tool in business research. European Business Review, 26(2), pp. 106-121. https://doi.org/10.1108/EBR-10-2013-0128.

Kebede, G. F. (2018). Social capital and entrepreneurial outcomes: Evidence from informal sector entrepreneurs in Ethiopia. The Journal of Entrepreneurship, 27(2), 209-242. https://doi.org/10.1177/0971355718781250

Kim, N., \& Shim, C. (2018). Social capital, knowledge sharing and innovation of small- and medium-sized enterprises in a tourism cluster. International Journal of Contemporary Hospitality Management, 30(6), 2417-2437. doi: 10.1108/ijchm-07-2016-0392

Leal-Rodríguez, A. L., \& Albort-Morant, G. (2016). Linking market orientation, innovation and performance: An empirical study on small industrial enterprises in Spain. Journal of Small Business Strategy, 26(1), 37-50.

Lee, S., Park, J.-G., \& Lee, J. (2015). Explaining knowledge sharing with social capital theory in information systems development projects. Industrial Management \& Data Systems, 115(5), 883-900. https://doi.org/10.1108/IMDS-012015-0017

Lee, J. C., Shiue, Y. C., \& Chen, C. Y. (2016). Examining the impacts of organizational culture and top management support of knowledge sharing on the success of software process improvement. Computers in Human Behavior, 54, 462-474. https://doi.org/10.1016/j.chb.2015.08.030

Lei, H., Khamkhoutlavong, M. and Le, P.B. (2021). Fostering exploitative and exploratory innovation through HRM practices and knowledge management capability: the moderating effect of knowledge-centered culture. Journal of Knowledge Management, Vol. ahead-of-print No. ahead-of-print. https://doi.org/10.1108/JKM-07-2020-0505

Muniady, R. A., Mamun, A. A., Rosli Mohamad, M., Yukthamarani Permerupan, P., \& Binti Zainol, N. R. (2015). The effect of cognitive and relational social capital on structural social capital and micro-enteprise performance. Sage Open, $5,1-9$. 
Muehlfeld, K., Rao Sahib, P., \& Van Witteloostuijn, A. (2012). A contextual theory of organizational learning from failures and successes: A study of acquisition completion in the global newspaper industry, 1981-2008. Strategic Management Journal, 33(8), 938-964.

Markovic, S., \& Bagherzadeh, M. (2018). How does breadth of external stakeholder co-creation influence innovation performance? Analyzing the mediating roles of knowledge sharing and product innovation. Journal of Business Research, 88, 173-186. https://doi.org/10.1016/j.jbusres.2018.03.028.

Moqbel, M., \& Nah, F. F. H. (2017). Enterprise social media use and impact on performance: The role of workplace integration and positive emotions. AIS Transactions on Human-Computer Interaction, 9(4), 261-280. https://doi.org/10.17705/1 thci.00098

Peridawaty, P., Toendan, R., \& Wenthe, I. (2021). The effects of entrepreneurial orientation and organizational learning on marketing capability in supply chain management. Uncertain Supply Chain Management, 9(1), 21-30.

Putra, I., Sunarsih, N., Novitasari, L., \& Setini, M. (2020). Exploring the relationship between social capital, innovation capability and innovation during the coronavirus pandemic. Uncertain Supply Chain Management, 8(4), 857-864. DOI: $10.5267 /$ j.uscm.2020.5.007

Quah, C. S., Sim, S. P. L., \& Tan, W. L. (2021). Academic Leadership Qualities Towards Innovation Endeavours in an Organisation: A Comparative Study of Malaysia and Singapore Perceptions. The Palgrave Handbook of Workplace Innovation, 371-389

Rumanti, I. A., Hairmansis, A., Nugraha, Y., Susanto, U., Wardana, P., Subandiono, R. E., ... \& Kato, Y. (2018). Development of tolerant rice varieties for stress-prone ecosystems in the coastal deltas of Indonesia. Field Crops Research, 223, 75-82. https://doi.org/10.1016/j.fcr.2018.04.006

Rass, M., Dumbach, M., Danzinger, F., Bullinger, A. C., \& Moeslein, K. M. (2013). Open innovation and firm performance: the mediating role of social capital. Creativity and Innovation Management, 22(2), $177-194$. https://doi.org/10.1111/caim.12028

Sanchez-Famoso, V., Pittino, D., Chirico, F., Maseda, A., \& Iturralde, T. (2019). Social capital and innovation in family firms: The moderating roles of family control and generational involvement. Scandinavian Journal of Management, 35(3), 101043.

Salehzadeh, R., Pool, J. K., Mohseni, A. M., \& Tahani, G. (2017). Factors influencing organisational performance: the role of knowledge sharing and organisational agility. International Journal of Business Excellence, 11(3), $344-356$. https://doi.org/10.1504/IJBEX.2017.081930

Sudari, S., Tarofder, A., Khatibi, A., \& Tham, J. (2019). Measuring the critical effect of marketing mix on customer loyalty through customer satisfaction in food and beverage products. Management Science Letters, 9(9), 1385-1396.

Sutono, A. (2019). Supply chain management: implementation issues and research opportunities in tourism industry. Uncertain Supply Chain Management, 7(3), 427-438.

Subramony, M., Segers, J., Chadwick C., \& Shyamsunder A. (2018). Leadership development practice bundles and organizational performance: The mediating role of human capital and social capital. Journal of Business Research, 83, 120-9. http://dx.doi.org/10.1016/j.jbusres.2017.09.044

Sugiyarti, G., Ferdinand, A.T., \& Nurchayat, T. (2018). Acculturative Products Uniqueness Antecedence for Successful Marketing Performance. DLSU Business \& Economics Review, 28, 86-96.

SSrisathan, W. A., Ketkaew, C., \& Naruetharadhol, P. (2020). The intervention of organizational sustainability in the effect of organizational culture on open innovation performance: A case of thai and chinese SMEs. Cogent business \& Management, 7(1), 1717408. https://doi.org/10.1080/23311975.2020.1717408

Thomas, B., Gornall, L., \& Murphy, L. (2018). Valuing European Partnerships: Memories of Cross-National Leadership in UK Higher Education Projects. Exploring Consensual Leadership in Higher Education: Co-operation, Collaboration and Partnership, 223.

Torres, A. P., Marshall, M. I., \& Sydnor, S. (2019). Does social capital pay off? The case of small business resilience after Hurricane Katrina. Journal of Contingencies and Crisis Management, 27(2), 168-181. http://dx.doi.org/10.1016/j.jbusres.2017.05.029

Tata, J., \& Prasad, S. (2015). Immigrant family businesses: social capital, network benefits and business performance. International Journal of Entrepreneurial Behavior \& Research, 21(6), 842-866. doi: 10.1108/IJEBR-06-2014-0111.

van Dijk, A., Hendriks, P., \& Romo-Leroux, I. (2016). Knowledge sharing and social capital in globally distributed execution. Journal of Knowledge Management, 20(2), 327-343. https://doi.org/10.1108/JKM-07-2015-0268

Zhang, D., Zhang, F., Lin, M. and Du, H.S. (2017). Knowledge sharing among innovative customers in a virtual innovation community: The roles of psychological capital, material reward and reciprocal relationship. Online Information Review, 41(5), 691-709. https://doi.org/10.1108/OIR-08-2016-0226

Zhou, J., Mavondo, F. T., \& Saunders, S. G. (2019). The relationship between marketing agility and financial performance under different levels of market turbulence. Industrial Marketing Management, 83, 31-41. https://doi.org/10.1016/j.indmarman.2018.11.008 
(C) 2021 by the authors; licensee Growing Science, Canada. This is an open access article distributed under the terms and conditions of the Creative Commons Attribution (CC-BY) license (http://creativecommons.org/licenses/by/4.0/). 